\title{
Organic Waste Composting: A Resource Recovery Approach towards Sustainable Environment
}

\author{
H. M. U. Aslam ${ }^{1,2}$, M. A. Butt ${ }^{2}$, F. Bareen ${ }^{2}$, M. Shafiq ${ }^{2}$, F. A. Butt ${ }^{3}$, M. Shahid ${ }^{2}$, A. \\ Javaid $^{2}$ and A. Husnain ${ }^{2}$ \\ ${ }^{I}$ Department of Chemistry, School of Science, University of Management and Technology, Johar Town, Lahore, \\ Pakistan \\ ${ }^{2}$ College of Earth and Environmental Sciences, University of the Punjab, Lahore, Pakistan \\ ${ }^{3}$ Environmental Governess, Albert-Ludwigs University, Freiburg, Germany
}

\begin{abstract}
Organic waste (including kitchen, garden/lawn, and agricultural waste) were subject to composting through static pile and soil pit composting techniques to determine the best method for managing the organic fraction of Municipal Solid Waste (MSW). These conventional methods were used with some innovations (by using soil as seed compost and aeration assembly) to increase the efficiency while keeping the process cost effective. Quantitative parameter analysis of initial feedstocks such as weight, moisture content (MC) and bulk density (BD) were measured before setting up each experiment. Temperature variation was monitored on a daily basis and measurement of $\mathrm{CO}_{2}$ emission on weekly basis. Moreover, mixing of feedstock for aeration and applying water for optimum moisture content were also subject to weekly activities. Final compost from each experiment was analyzed against physical and chemical parameters such as colour, $\mathrm{MC}, \mathrm{BD}$, water holding capacity, $\mathrm{pH}$ and electrical conductivity. Aerobic soil pit showed better results among other composting techniques with with $\mathrm{BD}$ of $530 \pm 0.01 \mathrm{~kg} / \mathrm{m}^{3}$, MC $37.40 \pm 0.26 \%$, water holding capacity $94 \pm 0.45 \%, \mathrm{pH} 8.00 \pm 0.10$ and electrical conductivity $1.06 \pm 14.42 \mathrm{dS} / \mathrm{m}$. Based on the experiment's results, there were two conclusions drawn, first the application of soil proved to be very helpful as seed compost in a static pile showing good results. Secondly, soil pit composting with modification of passive aeration also proved it as a potential technique to manage organic waste.
\end{abstract}

Keywords: Composting, Resource Recovery, Waste Management, Sustainability

\section{Introduction}

Municipal solid waste (MSW) is a type of waste that is generated from domestic, construction and commercial activities (Karak, Bhagat et al. 2012). MSW is normally sorted into six major categories and food waste or organic waste is the major category among them accounting for $55.86 \%$ of the waste generated. The remaining portion of the MSW comprises of textile, wood, rubber, plastic and paper waste (Zhou, Meng et al. 2014). The waste if left unattended can becomea serious issue as it causes problems such as odour, flies and deterioration in the quality of nearby water bodies through the production of leachate. It's not only hazardous to the environment but poses significant issues to the human health, deteriorate aesthetic value of the land and arises economic concerns for the countries (Marshall and Farahbakhsh 2013). About one-third of the organic scrap worldwide is generated from food waste (Bellemare, Çakir et al. 2017) and it is a main environmental and societal issue (Halloran, Clement et al. 2014). The fruit and vegetables waste (FVW) share the major constituents and is defined as that part of fruit and vegetable that is not fit for human consumption and discarded (Chang, Tsai et al. 2006) and mostly produced in wholesale markets throughout (Sitorus, Sukandar et al. 2013). There are different stages in food supply chain at which FVW generated that includes pre and post-consumer 
stages (Panda, Mishra et al. 2016). In the same way (Galanakis 2012) indicated that 15\% fruit and 25\% vegetables are wasted along food supply chain.

To manage such quantities of waste, there must be some effective strategies that would not only manage the waste but should be economically viable (Moh and Abd Manaf 2017). FVW is considered a cheap feedstock that is readily available for the recovery of energy, water and valuable ingredients/products.(Plazzotta, Manzocco et al. 2017). With reference to waste management hierarchy, reduction has the top priority that is mostly based on production techniques (Demirbas 2011) while FVW can be reused to only soil amendments and its direct reuse has been reviewed by (Clemente, Pardo et al. 2015).

Most preferred option

Fig. 1: Hierarchy of Waste Management

FVW is considered as degradable organic matter having high water content that can be used in various recycling strategies such as animal feed can also be treated with the help of anaerobic digestion and composting (Huang, Li et al. 2014), (Velmurugan 2011). Composting is one of the best options for waste management that converts the organic fraction of waste into organic compost and could be utilized in the agriculture fields to replace inorganic fertilizers (Qian, Shen et al. 2014; Wang, He et al. 2015; Proietti, Calisti et al. 2016). The application of compost can bound carbon to soil (Boldrin, Andersen et al. 2009) which can enhance its physical, chemical and biological properties and ultimately stabilize the nutrients. Reduction in the volume, mass and moisture content is considered as a major advantage of composting, when compared with fresh organic waste, which can minimize the requirements of transportation. Moreover, it may also be seen to protect the resources of surface and groundwater from leachate contamination. (Pan, Dam et al. 2012), (Larney, Sullivan et al. 2006).

With respect to pollution control, composting projects have the ability to reduce greenhouse gases therefore, considered as contributors towards sustainable development. (Rogger, Beaurain et al. 2011; De Bertoldi 2013). It can also control the spread of pathogens and parasites by killing harmful microorganisms (Nasreen and Qazi 2012). Among many benefits that are linked with composting, low investment and applicability on even limited quantity of waste are contrary to high-technology projects (Tumuhairwe, Tenywa et al. 2009). .

To achieve optimum degradation of MSW and to get desired results without releasing foul odors and emissions, various factors must be controlled such as temperature, $\mathrm{pH}$, moisture content and carbon to nitrogen $(\mathrm{C} / \mathrm{N})$ ratio (Zhou 2017), (Guo, Li et al. 2012). Compost quality varies depending upon the type of techniques used and the amount of materials like fruit and vegetable peels and ratio of different type of peels (Larney and Hao 2007) 
To make it aerobic it is also equipped with some means of turning so that aeration can be provided to the material. Its design is also helpful in the control of MC, temperature and effectively captures the offensive odour as well. The vessel is normally works manually but it can be made automatic to enhance its efficacy of degradation which can reduces the time of composting from 3-5 weeks to 10-14 days (Kerouac 2000) (Schaub and Leonard 1996).. A nested aeration method was also used to process the municipal solid waste (Rasapoor, Nasrabadi et al. 2009) in which material do not mix for aeration but it depends on natural air flows for this purpose. However, air flows can be provided with the help of perforated pipes, fans and blowers. On the other hand for turned windrows, the feedstock is mixed or turned to enhance the degradation by providing more air. (Schaub and Leonard 1996) A method of vermicomposting is also getting significant attention in which different species of worms usually earthworms are used to degrade the organic matter produce a compost called vermicompost (Ndegwa and Thompson 2001). A conventional method of processing organic waste is called Soil Pit Composting in which pits have been dug up in the ground and lined with clay to prevent water loss. The depth and width of these pits depends upon the soil conditions and quantity of waste being generated. (Inckel, de Smet et al. 2005), (Yaghmaeian, Malakootian et al. 2005).

The present study was to establish techniques for controlled composting of fruit and vegetable peels and evaluation of selective composting methods for the production of high quality compost.

\section{Methodology}

\section{Selection of Organic Waste}

Vegetable and fruit scrap is a source of Nitrogen and considered as greens, while browns are referred to dried leaves, wheat straw, rice straw, etc. that are enriched in Carbon. These browns and greens, were collected from different points of the University of the Punjab, (PU) Quaid-e- Azam Campus Lahore, Punjab, Pakistan, 31.496879, 74.295142. The organic waste components, collected on daily basis, were initially weighed and their Moisture Content (MC) and Bulk Density (BD) measurements were also made.

\section{Experimental Setups}

\section{Soil Microbes Assisted Static Pile Composting}

A static pile of size 1 cubic yard (0.765 cubic meters) was used in this experiment for which $1 \mathrm{~cm}$ pore size gauze was utilized. It was rolled it along the length, joining the edges and then emplacing it vertically into the ground.

To satisfy the appropriate carbon to nitrogen $(\mathrm{C} / \mathrm{N})$ ratio, nearly equal volumes of browns and greens were added to the pile. Weights of both browns and greens per cubic meter were determined and added in the pile.

\section{Moisture Content and C/N Ratio of Feedstock}

Moisture Content (MC) for this combination of browns and greens was calculated by the following formula:

$$
G=\frac{\left(W_{1} \times M_{1}\right)+\left(W_{2} \times M_{2}\right)}{W_{1}+W_{2}}
$$


Where: $\mathrm{G}=$ Moisture goal \%, M1 = Moisture content of greens \%, M2 = Moisture content of browns \%

$$
G=\frac{(5.18 \times 80)+(0.21 \times 35)}{5.18+0.21}=78 \%
$$

The value for M1 was determined practically after manual mixing of greens and taking a representative sample for moisture content determination and M2 was taken from the literature. Theoretical moisture content of the feedstock came out as $78 \%$ while that determined practically was $75 \%$.

$\mathrm{C} / \mathrm{N}$ ratio was calculated by the formula given as under:

$$
R=\frac{W_{1}\left[C_{1}\left(100-M_{1}\right)\right]+W_{2}}{W_{1}\left[N_{1}\left(100-M_{1}\right)\right]+W_{i}^{2}}
$$

Where: $\mathrm{R}=\mathrm{C} / \mathrm{N}$ ratio, $\mathrm{C} 1=$ Percentage carbon of greens, $\mathrm{C} 2=$ Percentage carbon of browns,

N1 = Percentage nitrogen of greens, N2 = Percentage nitrogen of browns

$$
R=\frac{5.18[20(100-80)]+0.21[60(100-35)]}{5.18[1(100-80)]+0.21[1(100-35)]}=25
$$

The values of carbon and nitrogen percentages of both greens and browns were taken from literature and the $\mathrm{C} / \mathrm{N}$ ratio came out as 25:1.(Trautmann and Krasny 2014)

\section{Establishing and Maintaining of Compost Pile}

According to the calculated weights, both waste and bulking agent were mixed together manually. After mixing thoroughly, a representative sample of $1 \mathrm{~kg}$ was taken to determine its MC. Lasagne layering with mixed material and soil was done inside the static pile gauze. Weakly turning and moisture was applied to the waste in the pile to provide appropriate conditions for assisting proper degradation.

\section{Soil Pit Composting}

For this experiment, two ditches of 3 feet depth and 3 feet diameter were dug up in the ground. Water was applied frequently to make the soil of ditches compact and to initiate the microbial activity in soil. The inner sides of ditches were lined with the mixture of water, wheat straw and clayey soil to achieve circular shape of ditch and internal volume of 1 cubic yard ( 0.765 cubic meters).

\section{Semi-Aerobic Soil Pit}

Ditch was properly watered first and then mixture of vegetable $\&$ fruit waste and leaves was added inside it. The ditch was covered with bundles of rice straw to retain moisture inside it. Weekly turning and application of moisture was also done on the basis of requirements. 
Aerobic Soil Pit

A cost effective method to make the soil pits aerobic was tried to implement in this experiment. For this purpose, 0.5 litre disposable water bottles were used by cutting the upper and lower curved parts of the bottles and joining them end to end with packing tape to make long pipes. To increase the air circulation, random perforations on these pipes were made. An assembly of these pipes was made by joining 4 pipes of 2.8 feet vertically and two horizontal pipes of 1.5 feet length.

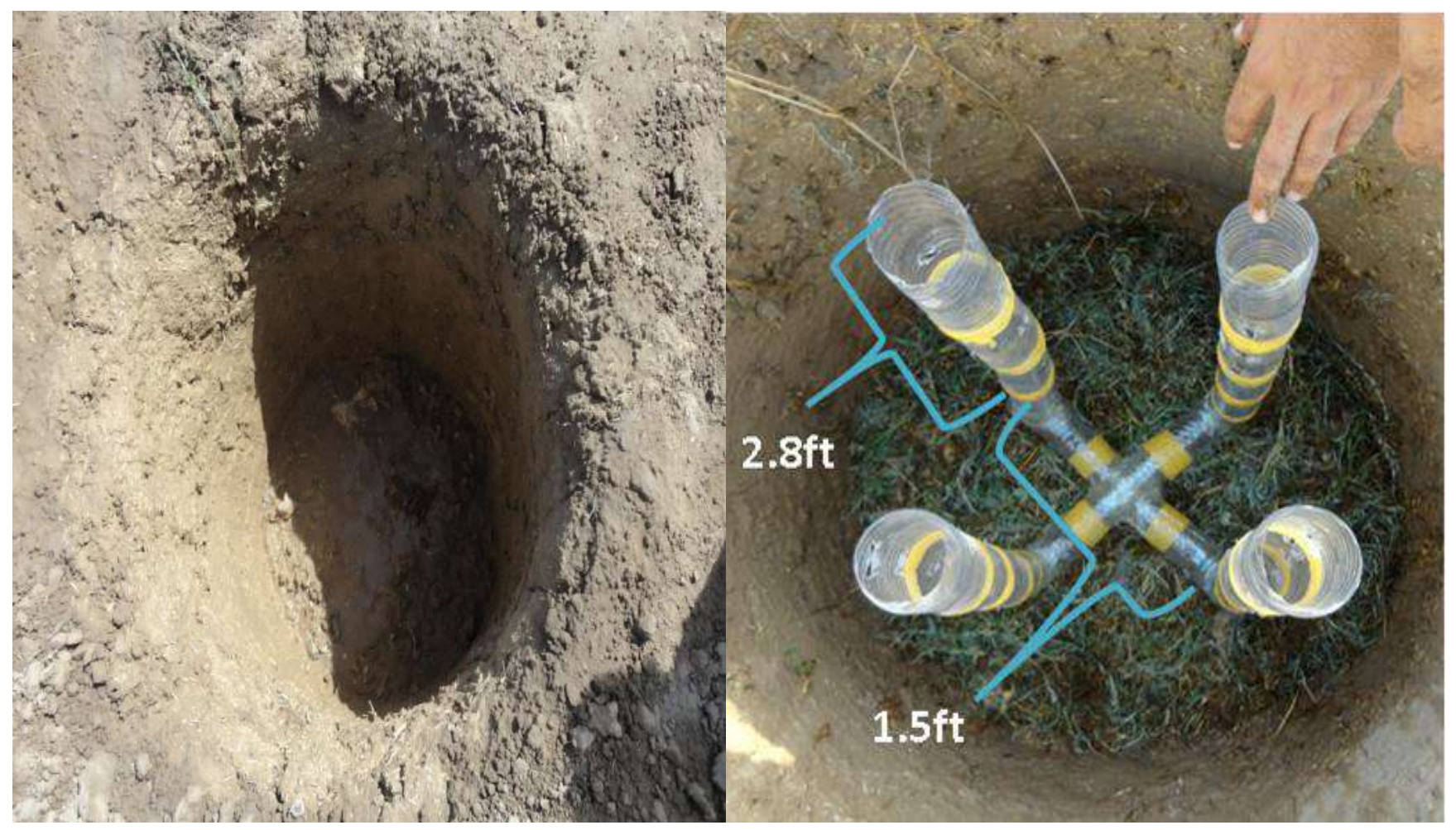

Fig. 3. (A) Soil pit. (B). Semi aerobic soil pit with perforated pipes

\section{Monitoring of Experiments}

Temperature: Compost thermometer (TEL TRU) having 1.5 feet long probe was used to measure temperature, from the center of the pile, twice a day at $9 \mathrm{am}$ and $4 \mathrm{pm}$ against the ambient temperatures to know the level of bacterial activity.

Carbon Dioxide Emission: Carbon dioxide is one of the major parameters which indirectly tell about the consumed oxygen during the composting process. Evolved carbon dioxide was measured by the alkali trap method of Kirita 1971(a) with some modifications. Solutions of KOH with three different concentrations i.e. $1 \mathrm{M}, 1.5 \mathrm{M}$ and $2 \mathrm{M}$ were used and their initial and final electrical conductivity (E.C.) was measured. The drop in E.C. of these solutions gave the amount of $\mathrm{CO} 2$ evolved through the formula given below: 


$$
\mathrm{CO}_{2}-\mathrm{Cg}^{-1} \text { soil }=22 \times \mathrm{P} \times \mathrm{V} \times \mathrm{C}
$$

Where: $\mathrm{P}=$ Proportional E.C. drop of sample trap

$\mathrm{V}=$ Volume of trap used,

$\mathrm{C}=$ Concentration $(\mathrm{M})$ of $\mathrm{OH}-1$ in trap

\section{Compost Analysis Parameters}

Prepared composts by different methods described above (after drying and sieving with $2 \mathrm{~mm}$ sieve) were then analyzed through different parameters.

\section{Physical Parameters}

Bulk density and MC of compost with particle size $2 \mathrm{~mm}$ was determined by already stated procedure. To determine water holding capacity, $100 \mathrm{ml}$ of air dried compost $(2 \mathrm{~mm})$ was filtered with filter paper and water holding capacity in percentage was calculated according to the following formula:

$$
\text { Waterholding capacity }(\%)=\left(\frac{\text { waterretained }}{100 \mathrm{ml}}\right) 100
$$

Where: Water retained $=$ water added - filtrate

\section{Chemical Parameters}

pH and Electrical Conductivity of the prepared compost was determined by multimeter (HI 9811-5).

\section{Results and Discussion}

\section{Physical Analyses of Waste Components \& Experiments}

Bulk density and moisture content: The BD and MC of the components are given in Table 1 .

Table 1. The $B D(\mathrm{~kg} / \mathrm{cu} y \mathrm{~d}) \pm S D$ and $M C(\%) \pm S D$ of the organic waste components

\begin{tabular}{llll}
\hline Sr. No. & Solid waste components & Bulk Density $(\mathrm{kg} / \mathrm{cu}$ yard $)$ & Moisture Content $(\%)$ \\
\hline 1 & Oranges & $306.52 \pm 95.05$ & $75.44 \pm 2.52$ \\
2 & Banana & $300.02 \pm 58.91$ & $86.59 \pm 6.38$ \\
3 & Apple & $304.83 \pm 144.35$ & $81.89 \pm 3.82$ \\
4 & Potato & $307.89 \pm 71.75$ & $66.81 \pm 17.07$ \\
5 & Carrot & $324.14 \pm 78.02$ & $77.57 \pm 14.24$ \\
6 & Cabbage & $233.17 \pm 27.40$ & $88.65 \pm 0.65$ \\
7 & Cucumber & $179.89 \pm 38.21$ & $81.68 \pm 14.26$ \\
\hline
\end{tabular}


The maximum value of bulk density was observed in carrot peels while the least was observed in cucumber peels as monitored on daily basis for a period of one month. In the same way maximum MC was observed in cabbage while potato showed least MC.

\section{Static Pile Composting}

Temperature Measurement: The figure 4 depicts the temperature fluctuations of the static pile when compared with ambient temperature. Initially, temperature rose rapidly and reached to 56oC within first 7 days while ambient temperature was lying to $45 \mathrm{oC}$. This high temperature was maintained for about 15 days and afterwards a gradual decline in the pile temperature was observed. This initial difference in temperature highlighted the role of soil dwelling microbes that increased the rate of decomposition of the waste. The consecutive peaks in the remaining portions of the graph indicated a sudden increase of pile temperature only when ambient temperature increases. Finally, it stabilized with ambient temperature at about $28 \mathrm{oC}$ and curing stage was achieved.

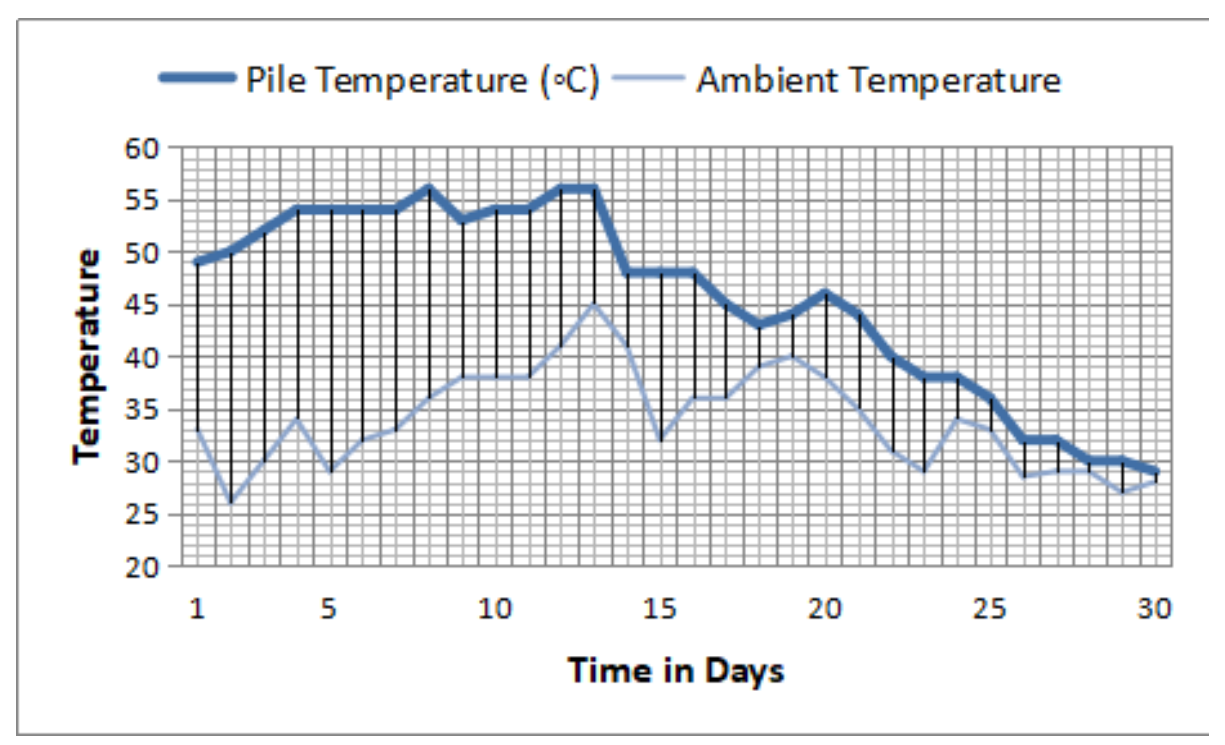

$(\circ \mathrm{C})$

Fig. 4. Graphical representation of temperature variation of soil microbes assisted static pile

CO2 estimation: Three molarities (1M, 2M, and 3M) of potassium hydroxide solution were used in the compost pile to check the amount of $\mathrm{CO} 2$ being released during the whole process. It can be observed from Table 2 that increase in molarities of the solutions have showed direct relation to the absorbance of $\mathrm{CO} 2$. As the molarities were increased, more amount of $\mathrm{CO} 2$ was absorbed in the solution.

Table 2. The observed initial and final mean E.C. $(\mathrm{ms} / \mathrm{cm}) \pm S D$ and mean CO2 emissions $(\mathrm{mg}) \pm S D$ from soil microbes assisted static pile

\begin{tabular}{lllll}
\hline Sr. No. & Molarity & $\begin{array}{l}\text { Initial E.C. } \\
(\mathrm{mS} / \mathrm{cm})\end{array}$ & $\begin{array}{l}\text { Final E.C. }(\mathrm{mS} / \mathrm{cm}) \\
\text { Mean } \pm \text { SD }\end{array}$ & $\begin{array}{l}\text { Amount of CO2 } \\
\text { (mg) Mean } \pm \text { SD }\end{array}$ \\
\hline 1 & 1 & 176 & $88.5 \pm 0.71$ & $590.7 \pm 28.00$ \\
& 0.5 & 93 & $44 \pm 2.83$ & \\
2 & 1.5 & 267 & $115 \pm 2.83$ & $1089 \pm 42.00$ \\
& 0.75 & 136 & $67 \pm 1.41$ & $1471 \pm 28.00$ \\
3 & 2 & 351 & $155.5 \pm 4.95$ & \\
& 1 & 176 & $88.5 \pm 0.71$ & \\
\hline
\end{tabular}




\section{Compost Analysis Parameters}

The compost prepared through static pile have shown a medium brown color which didn't depict a fully mature compost and therefore, a further short period of decomposition can result in the color most favorable for use i.e. blackish brown. MC, water holding capacity and conductivity values of this compost falls under the range of preferred standard values being compared as represented in Table 3.

Table 3. The observed mean physico-chemical analysis parameters \pm SD of soil microbe assisted static pile compost

\begin{tabular}{llll}
\hline Sr. No. & Parameter Nature & Parameter Name & Mean \pm SD \\
\hline 1 & & Bulk Density $(\mathrm{kg} / \mathrm{m} 3)$ & $689.78 \pm 0.69$ \\
2 & Physical & Moisture Content $(\%)$ & $43.00 \pm 1.00$ \\
3 & & Water Holding Capacity $(\%)$ & $120 \pm 0.81$ \\
4 & & $\mathrm{pH}$ & $9.60 \pm 0.36$ \\
5 & Chemical & Conductivity $(\mathrm{dS} / \mathrm{m})$ & $2.9 \pm 6.81$ \\
\hline
\end{tabular}

\section{Soil Pit Composting (Semi-aerobic)}

Temperature Measurement: The temperature variation in Figure 2 shows that the microbial activity was started soon after incorporating waste components into soil pit.

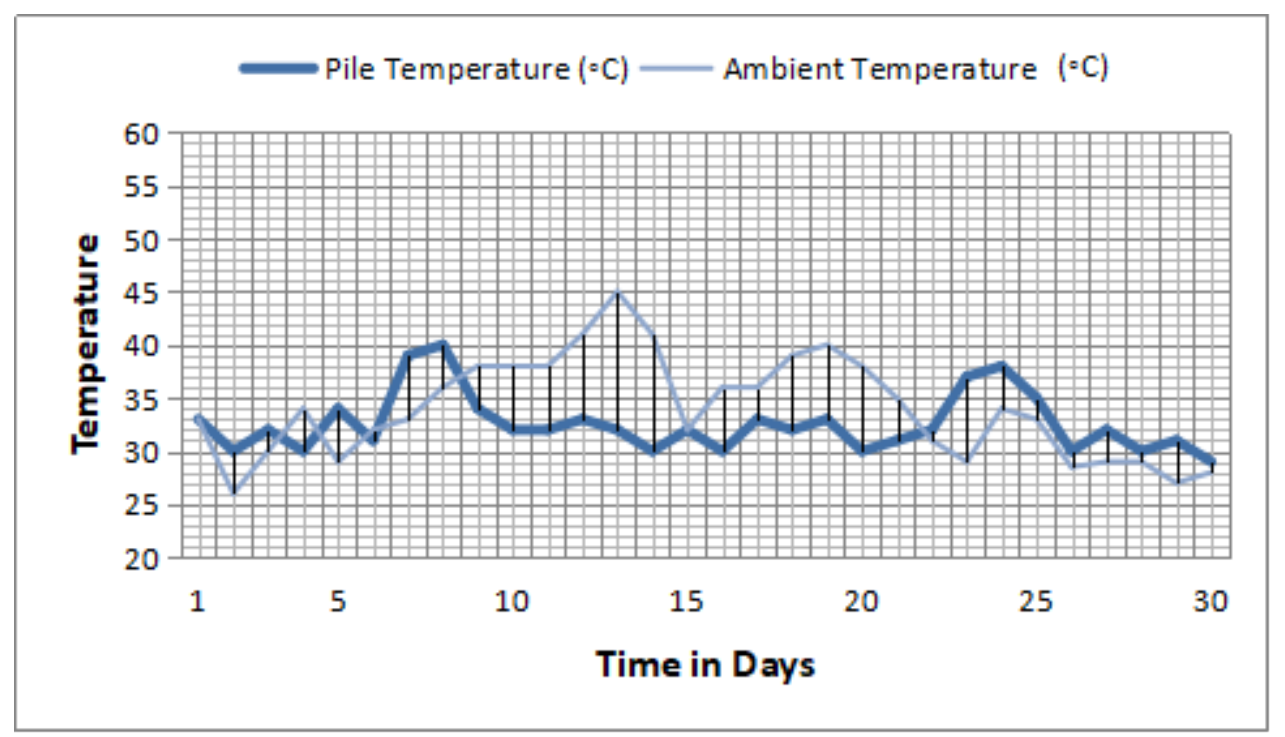

Figure 5. Graphical representation of temperature variation of semi aerobic soil pit with vegetables \& fruit scraps and dried leaves

Proper moisture and turning was applied which resulted in short term thermophilic phase shown by the temperature peak. But the activity was declined as the moisture was reduced. The continued decline in the microbial activity in Figure 2 was due to increased water content in the soil pit as a result of rain falls. Optimum temperature and $\mathrm{MC}$ was not maintained due to addition of extra water that disturbed the activity of the microbes and degradation process collapsed. It was the negative factor observed for open soil pit composting, 
the rain water retained in ditch as a result of heavy rainfalls which compacted the materials which led to the reduced air spaces ultimately reducing oxygen availability. This increased the an-aerobic degradation. Although the ambient temperature was quite high afterwards but the water retained in the pit hampered its microbial activity significantly.

$\mathrm{CO} 2$ estimation: The amount of $\mathrm{CO} 2$ released during this experiment, as represented in Table, is nearly the same to the values of first experiment i.e. soil microbes assisted static pile.

Table 4. The observed initial \& final mean E.C. $(\mathrm{mS} / \mathrm{cm}) \pm S D$ and values of mean $\mathrm{CO}_{2}$ emissions $(\mathrm{mg}) \pm S D$ from semi aerobic soil pit

\begin{tabular}{lllll}
\hline Sr. No. & Molarity & Initial E.C. $(\mathrm{mS} / \mathrm{cm})$ & $\begin{array}{l}\text { Final E.C. }(\mathrm{mS} / \mathrm{cm}) \\
\text { Mean } \pm \text { SD }\end{array}$ & $\begin{array}{l}\text { Amount of CO2 } \\
(\mathrm{mg}) \text { Mean } \pm \text { SD }\end{array}$ \\
\hline 1 & 1 & 166 & $81.5 \pm 0.71$ & $607.37 \pm 32.43$ \\
2 & 0.5 & 83 & $37 \pm 2.83$ & $1116.23 \pm 45.50$ \\
& 1.5 & 257 & $108 \pm 2.83$ & \\
3 & 0.75 & 126 & $60 \pm 1.41$ & $1504.9 \pm 27.86$ \\
\hline
\end{tabular}

\section{Soil Pit Composting (Aerobic)}

Temperature Measurement: Temperature variation in Figure 3 for soil pit shows a mesophilic stage when ambient temperature was high followed by a thermophilic stage and then the mesophilic stage again. Initial decline in the activity may be due to the insufficient moisture but as soon as the proper moisture and passive aeration was introduced, microbial activity increased significantly. The high temperature peaks represented that stage when passive aeration assembly was incorporated for air circulation.

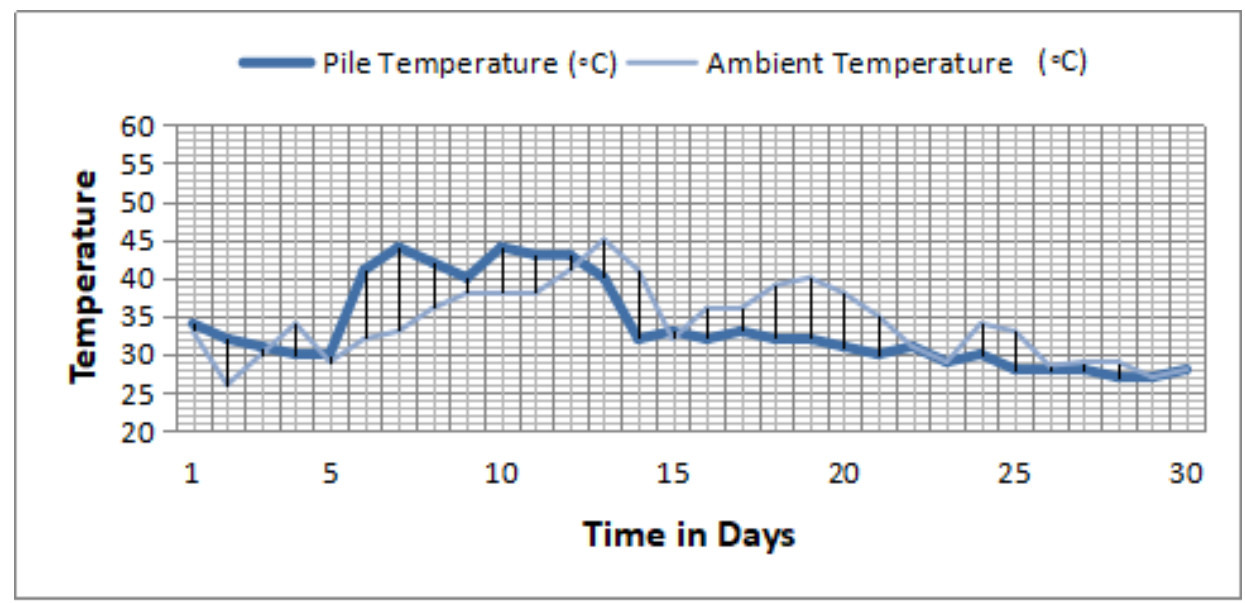

Figure 6. Graphical representation of temperature variation of aerobic soil pit with grass clippings and rice straw through duration of about one month

$\mathrm{CO}_{2}$ estimation: Released $\mathrm{CO}_{2}$ during this experiment was low when compared with other experiment. The decline in aerobic activity might be due to the nature of feed stock used. 
Table 5. The observed initial \& final mean E.C. $(\mathrm{mS} / \mathrm{cm}) \pm S D$ and values of mean CO2 emissions $(\mathrm{mg}) \pm S D$ from aerobic soil pit

\begin{tabular}{lllll}
\hline $\begin{array}{l}\text { Sr. } \\
\text { No. }\end{array}$ & Molarity & $\begin{array}{l}\text { Initial E.C. } \\
(\mathrm{mS} / \mathrm{cm})\end{array}$ & $\begin{array}{l}\text { Final E.C. }(\mathrm{mS} / \mathrm{cm}) \\
\text { Mean } \pm \text { SD }\end{array}$ & $\begin{array}{l}\text { Amount of CO2 } \\
(\mathrm{mg}) \\
\text { Mean } \pm \text { SD }\end{array}$ \\
\hline 1 & 1 & 143 & $138 \pm 1.41$ & $273.43 \pm 13.34$ \\
\hline & 0.5 & 73 & $67 \pm 1.41$ & $433.13 \pm 87.50$ \\
\hline & 1.5 & 236 & $229.5 \pm 0.71$ & \\
\hline & 0.75 & 112 & $104.5 \pm 0.71$ & $797.5 \pm 38.89$ \\
\hline
\end{tabular}

\section{Compost Analysis Parameters}

The color of the compost is medium brown in comparison to the blackish brown color of the finished compost, showing its partial decomposition, which also depicts its level of stability.

Table 6. The observed mean physico-chemical analysis parameters \pm SD of semi aerobic soil pit compost

\begin{tabular}{llll}
\hline Sr. No. & Parameter Nature & Parameter Name & Mean \pm SD \\
\hline 1 & Physical & Bulk Density $(\mathrm{kg} / \mathrm{m} 3)$ & $786.67 \pm 0.004$ \\
2 & & Moisture Content $(\%)$ & $53.333 \pm 1.53$ \\
3 & & \\
& & Water Holding Capacity (\%) & $92 \pm 0.25$ \\
4 & & $\mathrm{pH}$ & $8.53 \pm 0.25$ \\
5 & \multirow{2}{*}{ Chemical } & Conductivity $(\mathrm{dS} / \mathrm{m})$ & $0.79 \pm 15.28$ \\
\hline
\end{tabular}

The rest of the physical parameters are represented in Table 6 which includes moisture content and water holding capacity that are in the range given for standard compost parameter values, except bulk density which exceeds the range of typical value.

In Table 7 the light brown color of this compost shows that its quality is not up to the mark and is considered as immature compost. Its maturity can be achieved by providing further time to degradation. However, with this limited time of degradation, only bulk density falls under the preferred range while moisture content and water holding capacity lies in the typical standard values. In the same way $\mathrm{pH}$ and EC values also falls under the typical value range of compost. 
Table 7. The observed mean physico-chemical analysis parameters $\pm S D$ of aerobic soil pit compost

\begin{tabular}{llll}
\hline Sr. No. & Parameter Nature & Parameter Name & Mean \pm SD \\
\hline 1 & & Bulk Density $(\mathrm{kg} / \mathrm{m} 3)$ & $530 \pm 0.03$ \\
2 & Physical & Moisture Content $(\%)$ & $37.40 \pm 0.26$ \\
4 & & Water Holding Capacity (\%) & $94 \pm 0.45$ \\
4 & & $\mathrm{pH}$ & $8.00 \pm 0.10$ \\
5 & Chemical & Conductivity $(\mathrm{dS} / \mathrm{m})$ & $1.06 \pm 14.42$ \\
\hline
\end{tabular}

\section{Conclusion}

The fate of the solid waste, generated in the vicinity of Punjab University, is landfilling despite having the fact that it can be converted into organic product. In PU only dry leaves are being composted by using the technique of ditch composting while rest of the organic waste being wasted and simply dumped to landfill. Out of all the experiments being studied, static pile composting showed better results and can be adopted for the management of organic waste with proper turning and moisture maintenance. It is less labour intensive as compared to pit composting and requires less space. Moreover, the application of soil enhanced the efficiency of this technique due to the involvement of microbes.. Pit composting being the least efficient composting method was made efficient by applying aeration system which made it also a method of worth opting. However, weather conditions such as rain act as a limiting factor for all these practiced techniques and proper shed would be found beneficial in controlling the disturbance of rain and such sort of other factors.

\section{References}

Bellemare, M.F., M. Çakir, et al. (2017) - On the measurement of food waste American Journal of Agricultural Economics. 99, 5, 1148-1158.

Boldrin, A., J.K. Andersen, et al. (2009) - Composting and compost utilization: accounting of greenhouse gases and global warming contributions Waste Management \& Research. 27, 8, 800-812.

Chang, J.I., J.J. Tsai, et al. (2006) - Composting of vegetable waste Waste Manag Res. 24, 4, 354-362.

Clemente, R., T. Pardo, et al. (2015) - Food byproducts as amendments in trace elements contaminated soils Food Research International. 73, 176-189.

De Bertoldi, M. (2013) - The science of composting, Springer Science \& Business Media.

Demirbas, A. (2011) - Waste management, waste resource facilities and waste conversion processes Energy Conversion and Management. 52, 2, 1280-1287.

Gabhane, J., S.P. William, et al. (2012) - Additives aided composting of green waste: Effects on organic matter degradation, compost maturity, and quality of the finished compost Bioresource Technology. 114, 382-388.

Galanakis, C.M. (2012) - Recovery of high added-value components from food wastes: Conventional, emerging technologies and commercialized applications Trends in Food Science \& Technology. 26, 2, 68-87.

Guo, R., G. Li, et al. (2012) - Effect of aeration rate, $\mathrm{C} / \mathrm{N}$ ratio and moisture content on the stability and maturity of compost Bioresource Technology. 112, 171-178.

Halloran, A., J. Clement, et al. (2014) - Addressing food waste reduction in Denmark Food Policy. 49, 294-301.

Huang, K., F. Li, et al. (2014) - Effects of earthworms on physicochemical properties and microbial profiles during vermicomposting of fresh fruit and vegetable wastes Bioresour Technol. 170, 45-52.

Inckel, M., P. de Smet, et al. (2005) - The preparation and use of compost Agromisa foundations Wage-ningen seventh edition. 
Karak, T., R.M. Bhagat, et al. (2012) - Municipal Solid Waste Generation, Composition, and Management: The World Scenario Critical Reviews in Environmental Science and Technology. 42, 15, 1509-1630.

Kerouac, P.E. (2000) - Vessel composting process and apparatus, Google Patents.

Larney, F.J. and X. Hao. (2007) - A review of composting as a management alternative for beef cattle feedlot manure in southern Alberta, Canada Bioresource Technology. 98, 17, 3221-3227.

Larney, F.J., D.M. Sullivan, et al. (2006) - The role of composting in recycling manure nutrients Canadian Journal of Soil Science. 86, 4, 597-611.

Marshall, R.E. and K. Farahbakhsh. (2013) - Systems approaches to integrated solid waste management in developing countries Waste Management. 33, 4, 988-1003.

Moh, Y. and L. Abd Manaf. (2017) - Solid waste management transformation and future challenges of source separation and recycling practice in Malaysia Resources, Conservation and Recycling. 116, 1-14.

Nasreen, Z. and J.I. Qazi. (2012) - Lab scale composting of fruits and vegetable waste at elevated temperature and forced aeration Pak. J. Zool. 44, 5, 1285-1290.

Ndegwa, P. and S. Thompson. (2001) - Integrating composting and vermicomposting in the treatment and bioconversion of biosolids Bioresource Technology. 76, 2, 107-112.

Pan, I., B. Dam, et al. (2012) - Composting of common organic wastes using microbial inoculants 3 Biotech. 2 , $2,127-134$.

Panda, S.K., S.S. Mishra, et al. (2016) - Microbial-processing of fruit and vegetable wastes for production of vital enzymes and organic acids: Biotechnology and scopes Environ Res. 146, 161-172.

Plazzotta, S., L. Manzocco, et al. (2017) - Fruit and vegetable waste management and the challenge of fresh-cut salad Trends in Food Science \& Technology. 63, 51-59.

Proietti, P., R. Calisti, et al. (2016) - Composting optimization: Integrating cost analysis with the physicalchemical properties of materials to be composted Journal of Cleaner Production. 137, 1086-1099.

Qian, X., G. Shen, et al. (2014) - Co-composting of livestock manure with rice straw: Characterization and establishment of maturity evaluation system Waste Management. 34, 2, 530-535.

Rasapoor, M., T. Nasrabadi, et al. (2009) - The effects of aeration rate on generated compost quality, using aerated static pile method Waste Management. 29, 2, 570-573.

Rogger, C., F. Beaurain, et al. (2011) - Composting projects under the Clean Development Mechanism: sustainable contribution to mitigate climate change Waste Management. 31, 1, 138-146.

Schaub, S.M. and J.J. Leonard. (1996) - Composting: An alternative waste management option for food processing industries Trends in Food Science \& Technology. 7, 8, 263-268.

Sitorus, B., Sukandar, et al. (2013) - Biogas Recovery from Anaerobic Digestion Process of Mixed Fruit Vegetable Wastes Energy Procedia. 32, 176-182.

Trautmann, N. and M. Krasny (2014) - Composting in the Classroom: Scientific Inquiry for High School Students.

Tumuhairwe, J.B., J.S. Tenywa, et al. (2009) - Comparison of four low-technology composting methods for market crop wastes Waste Management. 29, 8, 2274-2281.

Velmurugan, B., and R. Alwar Ramanujam. (2011) - Anaerobic digestion of vegetable wastes for biogas production in a fed-batch reactor International Journal of Emerging Sciences. 1, 3, 478.

Wang, K., C. He, et al. (2015) - Transformation of organic matters in animal wastes during composting Journal of Hazardous Materials. 300, 745-753.

Yaghmaeian, K., M. Malakootian, et al. (2005) - Comparison between Windrow and Pit Composting of Poultry Wastes, Leaves and Garbage of Municipal Solid Waste in Damghan, Iran Journal of Environmental Health Science \& Engineering. 2, 1, 22-27.

Zhou, H., A. Meng, et al. (2014) - Classification and comparison of municipal solid waste based on thermochemical characteristics Journal of the Air \& Waste Management Association. 64, 5, 597-616.

Zhou, J.-M. (2017) - The Effect of Different C/N Ratios on the Composting of Pig Manure and Edible Fungus Residue with Rice Bran Compost Science \& Utilization. 25, 2, 120-129. 